\title{
Involvement of the solid phase of rumen digesta in the interaction between copper, molybdenum and sulphur in sheep
}

\author{
BY J. D. ALLEN* AND J. M. GAWTHORNE† \\ School of Veterinary Studies, Murdoch University, Murdoch, Western Australia 6150, \\ Australia
}

(Received 22 April 1986 - Accepted 19 March 1987)

\begin{abstract}
1. Merino sheep fed on a diet of chopped wheaten hay, chopped lucerne (Medicago sativa) hay and oat grain were the source of rumen contents for the study. The diet contained (mg/kg dry weight) 3.3 copper, 0.24 molybdenum and $2 \cdot 8$ sulphur. The effects of adding between 5 and $25 \mathrm{mg} \mathrm{Mo} / \mathrm{kg}$ as ammonium molybdate (AM) or tetrathiomolybdate (TTM) on the distribution and forms of $\mathrm{Cu}$ and $\mathrm{Mo}$ in rumen contents were investigated in vivo and in vitro.

2. Approximately $88 \%$ of the $\mathrm{Cu}$ and $94 \%$ of the Mo in rumen contents were associated with the solid phase. When AM or TTM was added to rumen contents in vivo or in vitro the proportion of these elements in the solid phase was increased at the expense of the fluid phase.

3. The addition of AM and TTM to rumen contents also decreased the proportion of $\mathrm{Cu}$ that was soluble in trichloroacetic acid $(50 \mathrm{~g} / 1$; TCA) and increased the proportion of $\mathrm{Cu}$ that was not extractable by sequential treatment with TCA and neutral detergent.

4. Column chromatography of neutral-detergent extracts of rumen contents revealed that TTM treatment caused $\mathrm{Cu}$ to be strongly bound to proteins of high molecular weight.

5. Addition of sulphide to rumen contents did not result in significant changes in the distribution of $\mathrm{Cu}$ between the fluid and solid phases, or in the solubility of $\mathrm{Cu}$ in TCA.

6. It is postulated that constant removal of TTM from the fluid phase via reaction with proteins and other macromolecules in the solid phase results in greater formation of TTM in vivo than would be expected from solution chemistry. The molybdo-proteins so formed are strong chelators of $\mathrm{Cu}$ and may be the agents responsible for the decrease in $\mathrm{Cu}$ absorption in animals that consume diets containing high concentrations of Mo.
\end{abstract}

When relatively high concentrations of molybdenum and sulphur are simultaneously present in the diet of ruminants the availability of copper to the animal is seriously compromised (Dick, 1956). The production of thiomolybdates in the rumen, and the subsequent decrease in the availability of $\mathrm{Cu}$ due to the formation of insoluble $\mathrm{Cu}$ thiomolybdates has been suggested as a hypothesis for the interaction (Dick et al. 1975). Confirmation of the hypothesis via spectrophotometric evidence of the presence of these compounds in rumen contents has been hampered by interference from other compounds, and by the low concentrations of Mo normally present. However, at moderately high molybdate concentrations, absorption spectra typical of thiomolybdates have been found in washed suspensions of rumen micro-organisms (Dick et al. 1975; El Gallad et al. 1983), in an artificial rumen apparatus (Bray et al. 1982), and in whole rumen contents (El Gallad et al. 1983), thereby indicating that the potential for thiomolybdate formation does exist.

Interest has also centred on the particular species of thiomolybdates that may occur in vivo. Based on observations of solution chemistry, Clarke \& Laurie (1980) concluded that tetrathiomolybdate (TTM) would not form unless the sulphide: Mo ratio was very high, and that at the lower ratios more likely to be present in the rumen, only mono-, di- or trithiomolybdates would form. In confirmation of this, Mason et al. (1982a) have detected trithiomolybdate but not TTM attached to plasma proteins of animals given Mo and S

* Present address: Attwood Veterinary Research Laboratory, Department of Agriculture, Westmeadows, Victoria 3047, Australia.

$\dagger$ For reprints. 
supplements. On the other hand, El Gallad et al. (1983) maintain that localized high ratios of sulphide: Mo in the rumen, and therefore TTM formation, cannot be ruled out. The controversy over the presence or absence of the tetra-species is significant, because this is the only form that has been shown to affect rats and sheep to the extent of inducing signs of $\mathrm{Cu}$ deficiency or of decreasing $\mathrm{Cu}$ absorption (Mills et al. 1981; Bremner et al. 1982; Suttle \& Field, 1983). Dithiomolybdate was not effective in either species, and trithiomolybdate was ineffective in rats, but has not been tested in sheep.

In the present paper we present evidence that the solid phase of rumen digesta consisting of micro-organisms and plant material plays a major role in the interaction between $\mathrm{Cu}$, Mo and S, and that thiomolybdates may be intermediate reactants only, in the formation of macromolecular $\mathrm{Cu}$ chelators. A preliminary report of the results has appeared elsewhere (Gawthorne et al. 1985).

\section{EXPERIMENTAL}

\section{Animals, treatments and collection procedures}

Rumen contents were obtained from 5- to 6-month-old Merino wethers fitted with permanent rumen fistulas. The animals were fed ad lib. on a basic diet consisting of $(\mathrm{g} / \mathrm{kg})$ 400 chopped wheaten hay, 400 chopped lucerne (Medicago sativa) hay, and 200 oat grain, supplemented with sodium sulphate to a total $\mathrm{S}$ concentration of $2.8 \mathrm{~g} / \mathrm{kg}$ dry matter (DM). The diet contained (mg/kg dry weight): $3.3 \mathrm{Cu}, 0.24 \mathrm{Mo}, 15.6 \mathrm{Zn}, 26.7 \mathrm{Fe}$. The sheep were fed once daily and samples of rumen digesta were obtained $3 \mathrm{~h}$ after feeding, via the rumen fistula, using a stainless-steel device similar to that described by Smith \& Marston (1970).

Addition of ammonium molybdate $(A M)$ and TTM in vitro. The in vitro experiments were conducted over a 2 year period on sheep selected from groups aged between 5 and 7 months. Equal quantities of digesta from four sheep fed on the basic diet were combined and used in the in vitro experiments. In some experiments TTM was added to samples of the combined rumen contents in vitro to final concentrations of 5 or $25 \mathrm{mg} \mathrm{Mo} / \mathrm{kg} \mathrm{DM}$. In other experiments, TTM and AM at concentrations of $15 \mathrm{mg} \mathrm{Mo} / \mathrm{kg} \mathrm{DM}$ were added singly or in combination with sodium sulphide $(33 \mathrm{mg} \mathrm{S} / \mathrm{kg} \mathrm{DM})$. All treatments were added within $1 \mathrm{~h}$ of collection, in a volume of distilled water that was $5 \%$ of the volume of the digesta samples. Samples were incubated at room temperature for $3-4 \mathrm{~h}$ with frequent mixing. Incubations were carried out in triplicate.

Addition of $A M$ and TTM in vivo. Twenty-five Merino wethers aged 6 months were divided into five groups with five animals in each group. For each group, the basic diet was supplemented as follows (mg/kg dry weight): control, 0 Mo; L-TTM, 5 Mo as TTM ; HTTM, 25 Mo as TTM; L-AM, 5 Mo as AM; H-AM, 25 Mo as AM. The sheep were given these treatments for 5 months and rumen samples were then taken from each animal, as described previously, and were fractionated and analysed individually.

\section{Preparation of TTM}

TTM was prepared by bubbling hydrogen sulphide through an alkaline solution of AM. The $\mathrm{H}_{2} \mathrm{~S}$ was formed in a Kipps apparatus and was passed through a water trap to remove hydrochloric acid fumes before they entered the AM solution. The purity of the TTM preparation was assessed by Mo analysis and column chromatography on Sephadex G-25 as described by Zumft (1978) and Mason et al. (1982b). The preparation contained $88 \%$ TTM, and negligible di- or trithiomolybdate. 


\section{Fractionation of rumen contents}

Rumen samples were stirred in a stainless-steel blender (Sorvall Omnimixer 17106) in order to achieve a thorough mix and to help separate absorbed protozoa and bacteria from plant material.

Rumen digesta were separated into four fractions: (1) strained-solids fraction (SS), consisting of the plant material, adherent bacteria, and protozoa, retained by straining the rumen contents through a vinyl cloth; (2) protozoal-rich fraction (PR), consisting of the precipitate obtained by centrifugation $(750 \mathrm{~g}$ for $10 \mathrm{~min}$ ) of the fluid that passed through the vinyl cloth in step 1. This fraction consisted of protozoa and fine plant material; (3) bacterial-rich fraction (BR), consisting of the precipitate obtained by centrifugation ( $25000 \mathrm{~g}$ for $30 \mathrm{~min}$ ) of the supernatant fraction from step 2. This fraction consisted of bacteria and very-fine plant particles; (4) supernatant fraction (SN), consisting of the supernatant fraction from step 3. This fraction contained the soluble components of the rumen contents.

\section{Analysis of rumen contents}

Rumen fractions were digested with $5 \mathrm{ml}$ nitric $(16 \mathrm{M}), 2 \mathrm{ml}$ perchloric $(12 \mathrm{M})$ and $2 \mathrm{ml}$ sulphuric acids $(18 \mathrm{M})$. Fractions were analysed for $\mathrm{Cu}$, zinc and iron by atomic absorption spectrophotometry (AAS) and for Mo by the method of Bingley (1963).

Fresh samples of rumen fluid were collected via a tube inserted through the rumen fistula and the concentration of acid-volatile sulphide in the samples was determined by the method described by Gawthorne \& Nader (1976).

\section{Solubility of $\mathrm{Cu}, \mathrm{Mo}, \mathrm{Zn}$ and $\mathrm{Fe}$ in rumen fractions}

Samples of SS fraction ( $2 \mathrm{~g}$ wet weight) or PR and BR fractions $(0.5 \mathrm{~g}$ wet weight) were mixed with $50 \mathrm{~g} / 1 \mathrm{TCA}$ in total volumes of $10 \mathrm{ml}$ (SS fraction) or $5 \mathrm{ml}$ (PR and BR fractions) and left to stand at room temperature. After $48 \mathrm{~h}$ the samples were centrifuged at $3000 \mathrm{~g}$ for $10 \mathrm{~min}$ and the supernatant fraction was retained. The residue precipitated by TCA was washed three times with the same volume of distilled water as TCA. The concentrations of $\mathrm{Cu}, \mathrm{Zn}$ and $\mathrm{Fe}$ in the TCA supernatant fraction and in the washings were determined directly by AAS and were combined to calculate the amounts of the elements solubilized by TCA.

The TCA-insoluble component of the rumen fraction was solubilized by an adaptation of the neutral-detergent fibre extraction method described by Van Soest \& Wine (1967). The TCA-insoluble residue was extracted with $10 \mathrm{ml}$ (SS fraction) or $5 \mathrm{ml}$ (PR and BR fractions) of a neutral-detergent solution containing (g/l) 30 sodium dodecyl sulphate (SDS), 6.8 sodium tetraborate, 4.6 disodium hydrogen phosphate and 10 2-ethoxy-ethanol. The samples were left to stand for $3 \mathrm{~h}$ at $60^{\circ}$ and then for $48 \mathrm{~h}$ at room temperature. The samples were centrifuged at $3000 \mathrm{~g}$ for $10 \mathrm{~min}$, and the concentrations of $\mathrm{Cu}, \mathrm{Zn}$ and $\mathrm{Fe}$ in the supernatant fraction were determined by AAS.

\section{Solubility of $\mathrm{Cu}$ in dietary fractions}

Samples of the diet were homogenized in distilled water to give a DM concentration similar to that of rumen contents $(98 \mathrm{~g} / \mathrm{kg})$. The solubility of dietary $\mathrm{Cu}$ in TCA was determined using this homogenate and the method described previously for rumen digesta.

\section{Column chromatography}

The forms of $\mathrm{Cu}$ present in the TCA- and detergent-supernatant fractions were separated by chromatography on a $15 \mathrm{~mm} \times 1000 \mathrm{~mm}$ column of Sephadex G-100, using an eluant of

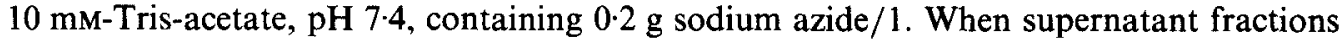


containing detergent were chromatographed, $30 \mathrm{~g} \mathrm{SDS} / 1$ were added to the eluant. Fractions $(3.5 \mathrm{ml})$ were collected at a flow rate of $28 \mathrm{ml} / \mathrm{h}$ and $\mathrm{Cu}, \mathrm{Zn}$ and $\mathrm{Fe}$ concentrations were determined directly by AAS.

\section{Statistical analyses}

In the in vitro experiments, involving two experimental groups, the results were analysed using an analysis of variance based on three replicate incubations per group. Experiments, involving five treatment groups, were analysed using a $2 \times 2+1$ factorial statistical analysis with the aid of a computer program (GENSTAT, Numerical Algorithms Ltd, Oxford). Orthogonal polynomials were used to determine the effect of in vitro additions of TTM on the acid solubility of $\mathrm{Cu}$ in the diet and fractions of the rumen digesta of sheep.

\section{RESULTS}

Effect of Mo compounds in vitro

Distribution. The distribution of $\mathrm{Cu}, \mathrm{Mo}, \mathrm{Zn}$ and $\mathrm{Fe}$ in rumen fractions before and after the addition of TTM in vitro is shown in Table 1. Each of the trace elements was predominantly associated with the SS fraction. The addition of TTM had no significant effect on the distribution of $\mathrm{Zn}$ and $\mathrm{Fe}$ but increased the proportion of $\mathrm{Cu}$ in the SS fraction at the expense of the $\mathrm{BR}$ and $\mathrm{SN}$ fractions.

TCA solubility. The solubility of $\mathrm{Cu}$ in TCA in each of the rumen fractions was markedly decreased by the addition of TTM in vitro. The relation between TCA-soluble $\mathrm{Cu}$, and TTM added within the range $0-25 \mathrm{mg} \mathrm{Mo} / \mathrm{kg}$ DM was

$$
y=a+b x+c x^{2}
$$

where $y$ was TCA-soluble $\mathrm{Cu}$ expressed as $\mathrm{mg} / \mathrm{kg}$ or $\%$, and $x$ was the TTM added (mg Mo/kg DM). The constant $a$ and coefficients $b$ and $c$ had the values shown in Table 2 for each fraction of rumen digesta. The solubilities of $\mathrm{Zn}$ and Fe in TCA were not affected by TTM treatment (results not shown). In the homogenized diet, TTM additions decreased the solubility of $\mathrm{Cu}$ in TCA, but to a lesser degree than in fractions of rumen contents (Table 2).

When $15 \mathrm{mg} \mathrm{Mo} / \mathrm{kg}$ were added as TTM or AM the TCA solubility of Cu decreased (Table 3). Sulphide added to the endogenous sulphide in rumen contents was without significant effect.

Neutral-detergent solubility. The amount of $\mathrm{Cu}$ solubilized by the addition of neutral detergent to the TCA-insoluble component of each fraction is shown in Table 4. Most of the TCA-insoluble $\mathrm{Cu}$ in TTM-treated fractions could not be solubilized by detergent and remained bound to the precipitate. In samples from control sheep, however, $90 \%$ of the $\mathrm{Cu}$ was solubilized by either TCA or neutral detergent.

Column chromatography. When TCA supernatant fractions of the SS fraction were chromatographed on Sephadex G-100, Cu was found in low-molecular-weight (MW) fractions having an elution volume $\left(V_{e}\right)$ : void volume $\left(V_{o}\right)$ value of 5.9 (results not shown). However, in detergent extracts from the same fractions, $\mathrm{Cu}$ was associated with large- to medium-MW compounds (Fig. 1). The large-MW compound eluted at the void volume $\left(V_{e}: V_{o} 1 \cdot 0\right)$, and was present in TTM-treated and untreated samples, but the medium-MW compound $\left(V_{e}: V_{o} \cdot 1\right)$ was observed in the untreated sample only.

Similar profiles were observed for detergent extracts of the PR and BR fractions except that a medium-MW compound was present in TTM-treated and untreated samples and a third low-MW compound $\left(V_{e}: V_{o} 3 \cdot 3\right)$ was found in BR samples (results not shown). The $\mathrm{Cu}$ peaks corresponded with peaks of absorbance at $280 \mathrm{~nm}$. Two high-MW Zn and $\mathrm{Fe}$ 
Table 1. Effect of additions of tetrathiomolybdate (TTM) on the percentage distribution of trace elements in fractions of the rumen digesta of sheep in vitro

\begin{tabular}{|c|c|c|c|c|c|}
\hline Element & Treatment & $\begin{array}{l}\text { Strained } \\
\text { solids }\end{array}$ & $\begin{array}{l}\text { Protozoal } \\
\text { rich }\end{array}$ & $\begin{array}{l}\text { Bacterial } \\
\text { rich }\end{array}$ & $\begin{array}{l}\text { Supernatant } \\
\text { fraction }\end{array}$ \\
\hline Copper & $\begin{array}{l}\text { TTM } \\
0 \\
\text { SED }\end{array}$ & $\begin{array}{r}56 \cdot 7 \\
41.5 \\
2.6\end{array}$ & $\begin{array}{r}19 \cdot 5 \\
20.8 \\
1.1\end{array}$ & $\begin{array}{r}18 \cdot 9 \\
25 \cdot 8 \\
2 \cdot 0\end{array}$ & $\begin{array}{r}4.8 \\
11.8 \\
0.8\end{array}$ \\
\hline Molybdenum & $\begin{array}{l}\text { TTM } \\
0 \\
\text { SED }\end{array}$ & $\begin{array}{r}49 \cdot 9 \\
45 \cdot 1 \\
4 \cdot 3\end{array}$ & $\begin{array}{r}27.9 \\
19.1 \\
1.7\end{array}$ & $\begin{array}{r}18 \cdot 9 \\
30 \cdot 2 \\
2 \cdot 4\end{array}$ & $\begin{array}{l}3 \cdot 3 \\
5 \cdot 6 \\
1 \cdot 1\end{array}$ \\
\hline Zinc & $\begin{array}{l}\text { TTM } \\
0 \\
\text { SED }\end{array}$ & $\begin{array}{r}51 \cdot 2 \\
48 \cdot 0 \\
6 \cdot 4\end{array}$ & $\begin{array}{r}24 \cdot 2 \\
31 \cdot 2 \\
6 \cdot 1\end{array}$ & $\begin{array}{r}16 \cdot 7 \\
13 \cdot 6 \\
1 \cdot 8\end{array}$ & $\begin{array}{l}7.9 \\
7 \cdot 3 \\
0.9\end{array}$ \\
\hline Iron & $\begin{array}{l}\text { TTM } \\
0 \\
\text { SED }\end{array}$ & $\begin{array}{r}54 \cdot 1 \\
56 \cdot 5 \\
2.9\end{array}$ & $\begin{array}{r}22 \cdot 4 \\
23 \cdot 7 \\
1 \cdot 2\end{array}$ & $\begin{array}{r}11.9 \\
10.0 \\
1.5\end{array}$ & $\begin{array}{l}9 \cdot 3 \\
9 \cdot 8 \\
0.8\end{array}$ \\
\hline
\end{tabular}

Residual df, 4.

TTM, added to a concentration of $5 \mathrm{mg} \mathrm{Mo} / \mathrm{kg}$ dry matter in vitro; SED, standard error of the difference.

Table 2. Effect of in vitro additions of tetrathiomolybdate (TTM) on the acid solubility of copper in the diet and fractions of the rumen digesta of sheep

(The effect of increments of TTM $(5,15$ or $25 \mathrm{mg} \mathrm{Mo} / \mathrm{kg} \mathrm{DM})$ is represented by the equation $y=$ $a+b x+c x^{2}$ where $y$ represents the concentration of total $\mathrm{Cu}$, or TCA-soluble $\mathrm{Cu}$ or the percentage of total $\mathrm{Cu}$ soluble in TCA, and $x$ represents the concentration of Mo added as TTM to the sample. The analysis is based on three replicate incubations per group)

\begin{tabular}{|c|c|c|c|c|}
\hline Fraction & & $\begin{array}{c}\text { Total Cu } \\
\text { (mg/kg DM) }\end{array}$ & $\begin{array}{c}\text { TCA-soluble Cu } \\
\text { (mg/kg DM) }\end{array}$ & $\begin{array}{l}\text { TCA-soluble Cu } \\
\text { (\% of total) }\end{array}$ \\
\hline Strained solids & $\begin{array}{l}\text { Constant }(a) \\
\text { Coefficient } x(b) \\
\text { SE } \\
\text { Coefficient } x^{2}(c) \\
\text { SE } \\
\text { Residual SD (8 df) }\end{array}$ & $\begin{array}{c}5.8 \\
-0.14 \\
0.05 \\
- \\
- \\
0.47\end{array}$ & $\begin{array}{c}3.4 \\
-0.32 \\
0.06 \\
- \\
- \\
0.38\end{array}$ & $\begin{array}{r}56.9 \\
-4.65 \\
0.84 \\
0 \cdot 10 \\
0.03 \\
5.21\end{array}$ \\
\hline Protozoal rich & $\begin{array}{l}\text { Constant }(a) \\
\text { Coefficient } x(b) \\
\text { SE } \\
\text { Coefficient } x^{2}(c) \\
\text { SE } \\
\text { Residual SD (8 df) }\end{array}$ & $\begin{array}{c}45 \cdot 6 \\
-1 \cdot 36 \\
1 \cdot 10 \\
- \\
- \\
10 \cdot 11\end{array}$ & $\begin{array}{c}33 \cdot 0 \\
-3.94 \\
0.61 \\
0 \cdot 11 \\
0.02 \\
2.63\end{array}$ & $\begin{array}{r}73 \cdot 9 \\
-8 \cdot 37 \\
1 \cdot 35 \\
0.23 \\
0.05 \\
7 \cdot 33\end{array}$ \\
\hline Bacterial rich & $\begin{array}{l}\text { Constant }(a) \\
\text { Coefficient } x(b) \\
\text { SE } \\
\text { Coefficient } x^{2}(c) \\
\text { SE } \\
\text { Residual SD (8 df) }\end{array}$ & $\begin{array}{c}78.2 \\
-1 \cdot 14 \\
1.63 \\
- \\
-- \\
14.75\end{array}$ & $\begin{array}{r}27 \cdot 7 \\
-3 \cdot 61 \\
0 \cdot 67 \\
0 \cdot 10 \\
0.03 \\
2 \cdot 16\end{array}$ & $\begin{array}{c}35 \cdot 3 \\
-4.50 \\
0.84 \\
0.13 \\
0.03 \\
3 \cdot 12\end{array}$ \\
\hline Sheep diet ${ }^{*}$ & $\begin{array}{l}\text { Constant }(a) \\
\text { Coefficient } x(b) \\
\quad \text { SE } \\
\text { Coefficient } x^{2}(c) \\
\text { Residual SD (8 df) }\end{array}$ & $\begin{array}{l}3 \cdot 3 \\
0 \cdot 00 \\
0 \cdot 04 \\
-- \\
0 \cdot 37\end{array}$ & $\begin{array}{c}2.3 \\
-0.09 \\
0.03 \\
- \\
0.26\end{array}$ & $\begin{array}{c}72.0 \\
-2.60 \\
1.07 \\
-\overline{9}\end{array}$ \\
\hline
\end{tabular}

TCA, trichloroacetic acid ( $50 \mathrm{~g} / 1) ; \mathrm{DM}$, dry matter.

* Sheep diet was homogenized in distilled water, at the same DM content as rumen digesta. 
Table 3. Effect of additions of molybdenum and sulphur compounds on the acid solubility of copper in fractions of the rumen digesta of sheep in vitro

\begin{tabular}{|c|c|c|c|c|}
\hline Fraction & Treatment & $\begin{array}{c}\text { Total Cu } \\
(\mathrm{mg} / \mathrm{kg} \mathrm{DM})\end{array}$ & $\begin{array}{l}\text { TCA-soluble Cu } \\
(\mathrm{mg} / \mathrm{kg} \mathrm{DM})\end{array}$ & $\begin{array}{c}\text { TCA-soluble } \\
\mathrm{Cu}(\% \text { of total) }\end{array}$ \\
\hline Strained solids & $\begin{array}{l}\text { TTM } \\
\text { AM+S } \\
\text { AM } \\
\text { S } \\
0 \\
\text { SED }\end{array}$ & $\begin{array}{l}7 \cdot 2 \\
7 \cdot 1 \\
7 \cdot 1 \\
5 \cdot 9 \\
6 \cdot 9 \\
0 \cdot 9\end{array}$ & $\begin{array}{l}1 \cdot 3 \\
1.5 \\
1.7 \\
3.6 \\
3 \cdot 7 \\
0 \cdot 3\end{array}$ & \begin{tabular}{r|}
$18 \cdot 1$ \\
$21 \cdot 1$ \\
$23 \cdot 9$ \\
$60 \cdot 4$ \\
$53 \cdot 6$ \\
$6 \cdot 0$
\end{tabular} \\
\hline Protozoal rich & $\begin{array}{l}\text { TTM } \\
\text { AM + S } \\
\text { AM } \\
\text { S } \\
0 \\
\text { SED }\end{array}$ & $\begin{array}{r}52 \cdot 8 \\
54 \cdot 8 \\
57 \cdot 9 \\
62 \cdot 4 \\
65 \cdot 4 \\
6 \cdot 6\end{array}$ & $\begin{array}{r}7 \cdot 8 \\
16 \cdot 8 \\
8 \cdot 5 \\
37 \cdot 1 \\
46 \cdot 8 \\
4 \cdot 4\end{array}$ & $\begin{array}{r}14 \cdot 8 \\
30 \cdot 7 \\
14 \cdot 7 \\
59 \cdot 5 \\
71.6 \\
5.5\end{array}$ \\
\hline Bacterial rich & $\begin{array}{l}\text { TTM } \\
\text { AM +S } \\
\text { AM } \\
\text { S } \\
0 \\
\text { SED }\end{array}$ & $\begin{array}{r}100 \cdot 3 \\
115 \cdot 0 \\
98 \cdot 6 \\
105 \cdot 5 \\
107 \cdot 9 \\
13 \cdot 0\end{array}$ & $\begin{array}{r}9.1 \\
17.8 \\
11.8 \\
57.9 \\
62.8 \\
3.2\end{array}$ & $\begin{array}{r}9 \cdot 1 \\
15 \cdot 5 \\
12 \cdot 0 \\
54 \cdot 9 \\
58 \cdot 2 \\
4 \cdot 7\end{array}$ \\
\hline
\end{tabular}

Residual df, 10 .

TCA, trichloroacetic acid (50 g/l); DM, dry matter; TTM, tetrathiomolybdate (15 mg Mo/kg DM); AM, ammonium molybdate (15 mg Mo/kg DM); S, sulphide (33.1 mg S/kg DM). SED, standard error of the difference.

peaks eluted at the void volume, and two low-MW peaks $\left(V_{e}: V_{o} 3 \cdot 1-3 \cdot 4\right)$ were found in all detergent extracts (Fig. 1). No differences were observed between TTM-treated and untreated samples.

\section{Effect of Mo compounds in vivo}

TTM and AM given per fistulum at concentrations equivalent to $5 \mathrm{mg} \mathrm{Mo} / \mathrm{kg}$ or $25 \mathrm{mg}$ $\mathrm{Mo} / \mathrm{kg}$ in the diet, decreased $\mathrm{Cu}$ concentration in the $\mathrm{SN}$ fraction by approximately $50 \%$ (Table 5).

Supplements of TTM or AM increased the concentrations of Mo in all fractions, but with a proportionately greater increase in the $\mathrm{SN}$ fraction (Table 5).

In sheep from all groups, the mean sulphide concentrations in rumen fluid samples varied from 5.8 to $6.3 \mathrm{mg} \mathrm{S} / \mathrm{ml}$ and were not significantly affected by Mo treatment.

In all fractions of rumen contents, Mo supplementation decreased the proportion of $\mathrm{Cu}$ that was soluble in TCA (Table 5), but had no effect on that of $\mathrm{Zn}$ or Fe (results not shown). Additional $\mathrm{Cu}$ was solubilized by extraction of TCA-insoluble material with neutral detergent (Table 5).

After TCA and neutral-detergent extraction, $29-78 \%$ of the $\mathrm{Cu}$ remained unextracted in samples from animals receiving Mo supplements, but only 1-6\% in samples from control animals (Table 5). For each fraction of rumen contents, the proportion that could not be solubilized was greater at the higher level of Mo supplementation (Table 5).

\section{DISCUSSION}

The results reported here demonstrate that the solid phase contributes a major part of the total amount of $\mathrm{Cu}, \mathrm{Mo}, \mathrm{Zn}$ and $\mathrm{Fe}$ in sheep rumen contents and this confirms similar findings by Durand \& Kawashima (1979) and Grace \& Suttle (1979). The association of 
$\mathrm{Cu}, \mathrm{Mo}, \mathrm{S}$ interactions in rumen contents

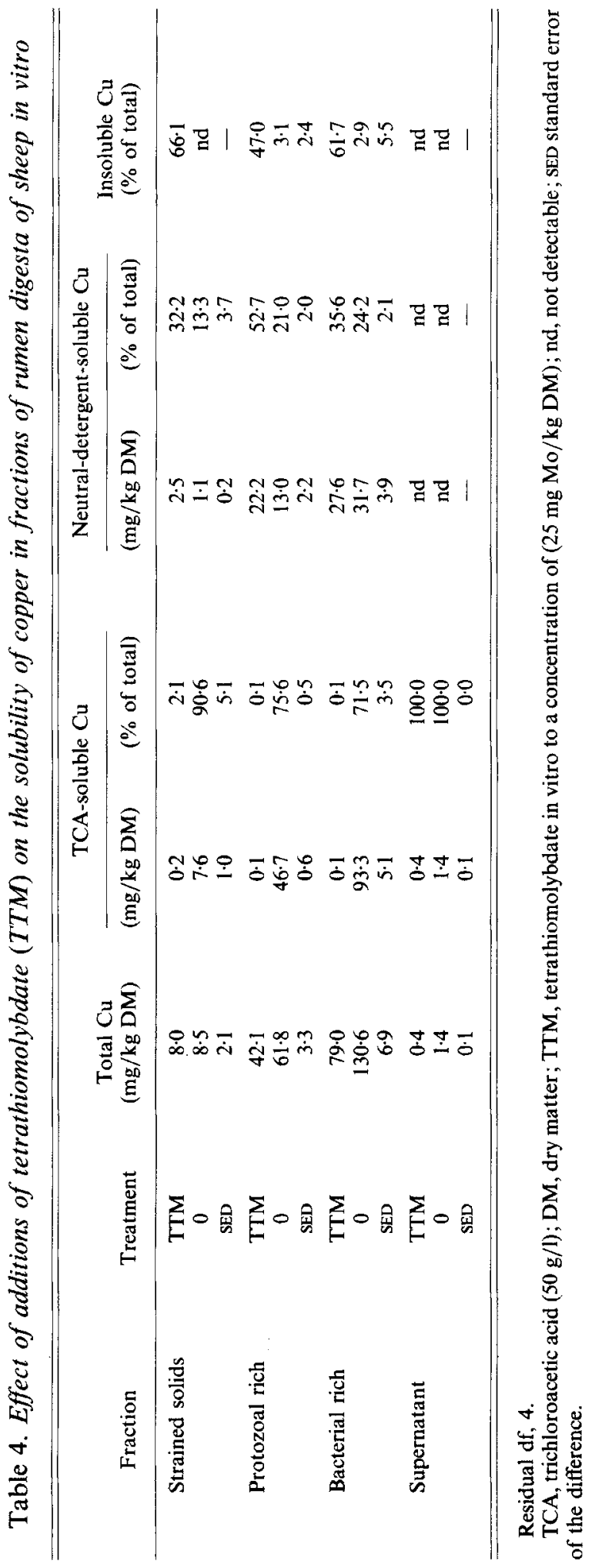



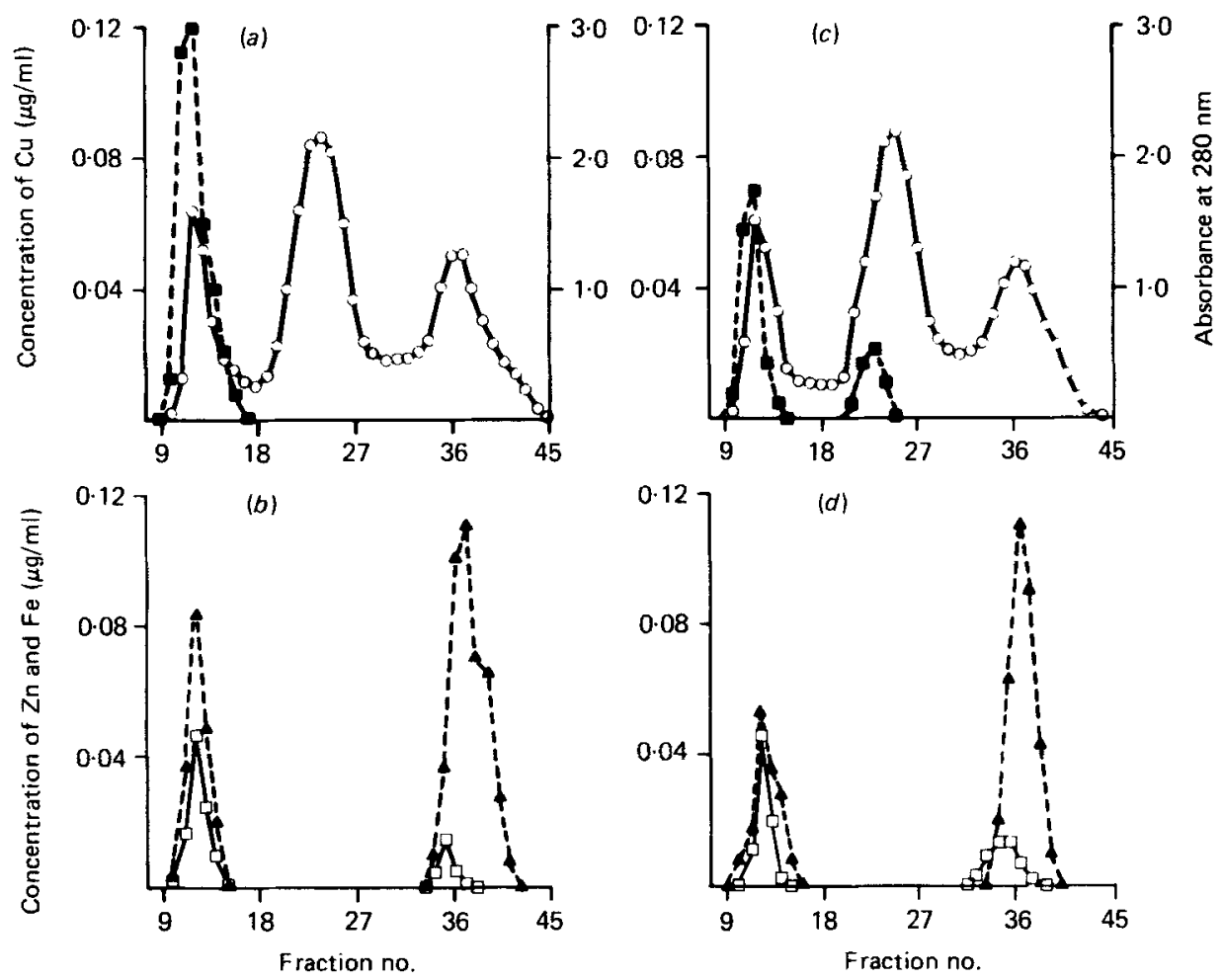

Fig. 1. Sephadex G-100 chromatography of detergent extracts from strained-solids fraction of rumen digesta: $(a)$ and $(b)$ after in vitro addition of tetrathiomolybdate $(25 \mathrm{mg}$ molybdenum $/ \mathrm{kg}$ ) to rumen digesta; $(c)$ and $(d)$, no addition of tetrathiomolybdate. Samples of detergent extract $(6 \mathrm{ml})$ were applied to the column $(15 \mathrm{~mm} \times 1000 \mathrm{~mm})$ and were eluted with $10 \mathrm{~mm}$-Tris-acetate, $\mathrm{pH} 7 \cdot 4$, containing $0.2 \mathrm{~g}$ sodium azide $/ 1$ and $30 \mathrm{~g}$ sodium dodecyl sulphate/ 1 . Fractions $(3.5 \mathrm{ml}$ ) were collected. ( $\square$ ) $\mathrm{Cu},(\square) \mathrm{Zn}$, (A) Fe, (O) absorbance at $280 \mathrm{~nm}$.

these elements with the solid phase is due to their occurrence in plant material and adherent micro-organisms. Several plant proteins containing $\mathrm{Cu}, \mathrm{Mo}, \mathrm{Zn}$ or $\mathrm{Fe}$ have been discovered, and many of them possess enzymic functions (Hewitt, 1983). Bremner (1970) showed that the water solubility of $\mathrm{Cu}$ and $\mathrm{Zn}$ in samples of rumen contents was lower than that in the corresponding diet of dried grass, and that an increased proportion of the elements was extracted from rumen contents with SDS. This indicated that the minerals in the diet had been incorporated or associated with microbial proteins. The occurrence and functions of trace elements in rumen micro-organisms have been reviewed by Durand \& Kawashima (1979).

In the present study, TTM and AM caused several changes in the concentrations and forms of $\mathrm{Cu}$ in the rumen fractions. Similar effects were observed with both the in vitro and the in vivo administration of these compounds. The increased incorporation of $\mathrm{Cu}$ into the solid phase (Tables 1 and 5) is consistent with the findings of Chesters et al. (1982). It may have arisen from the reaction of $\mathrm{Cu}$ with thiomolybdates adsorbed on dietary material, or absorbed into bacteria. The latter has been observed in Clostridium pasteurianum (Zumft, 1978).

The decrease in the proportion of TCA-soluble $\mathrm{Cu}$ in the solid phase after the addition of TTM is evidence that the $\mathrm{Cu}$ was in different forms to that in unsupplemented samples. A decrease in TCA solubility was observed in SS, PR and BR fractions, was dependent on 
$\mathrm{Cu}, \mathrm{Mo}, \mathrm{S}$ interactions in rumen contents

b

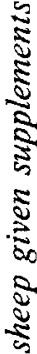

竞

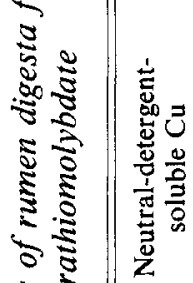

空

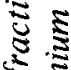

.

ริ

竎

$\frac{2}{5}$

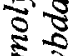

จ

¿

过

จ

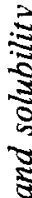

ร

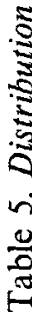

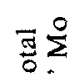

要

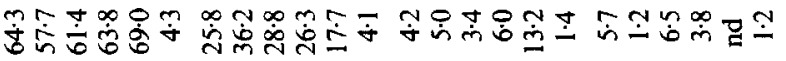

을

$\sum \stackrel{\sum}{2}$

西

离

已)

을

递

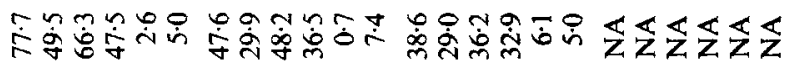

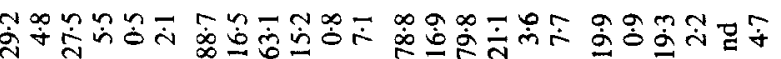

홍

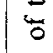

(1)

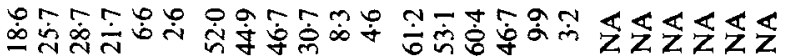

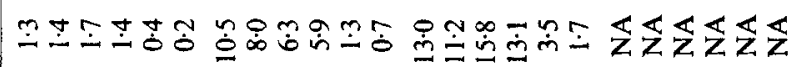

3
0
0
3
0
0
0
0

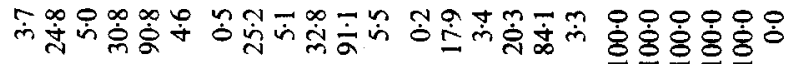

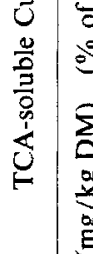

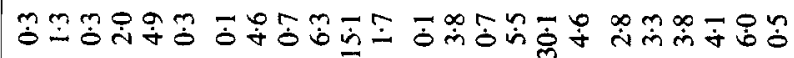

풍.

응

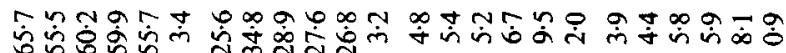
s롤

光方

要

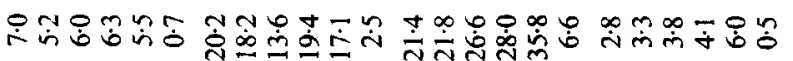

焉

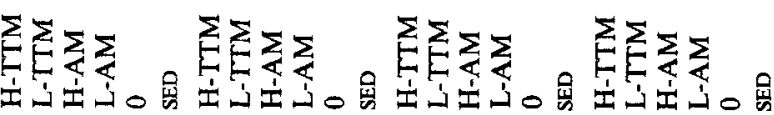

芯

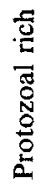

$\pm$

马ำ

交范

弯

莺

$\sum$

I

$\sum$

통

I

这

更

穵

$\cong \underset{1}{\leftrightarrows}$

岩

to

F

는

焉

突

닝

氖

的

일

런

它交

这

尊

원

홍ํㅇ

¿ำ

洪。

氖产

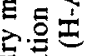

점 훈

范范

등

को

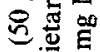

马्व

乌ั

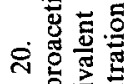

글

焉宣

买

远 
the amount of TTM added, and was specific for $\mathrm{Cu}$. The solubility of $\mathrm{Zn}$ and Fe was not affected. Similar changes were observed when TTM was homogenized with the diet, but the extent of the changes was smaller. Taken together, these observations suggest that the activity or presence of bacteria and protozoa enhance the conversion of $\mathrm{Cu}$ to TCAinsoluble forms when TTM is added to rumen contents.

Some $\mathrm{Cu}$-containing material was extracted from the TCA precipitates with neutral detergent. The neutral detergent method solubilizes almost all components in rumen contents except plant and bacterial cell walls (Van Soest, 1966; Van Soest \& Wine, 1967). Chromatographs of detergent extracts showed increased $\mathrm{Cu}$-containing material of high MW that corresponded with a peak of absorption at $280 \mathrm{~nm}$, suggesting that increased amounts of $\mathrm{Cu}$ were associated with proteins after the addition of TTM.

In some experiments the addition of TTM in vitro resulted in an apparent decrease in the total concentration of $\mathrm{Cu}$ in fractions of rumen digesta, particularly in the BR fraction (Tables 2 and 4). This was not a consistent effect and was attributed to sampling variations exacerbated by the small size of samples left for determination of total $\mathrm{Cu}$ concentrations.

The in vitro and in vivo effects of AM administration were similar to those induced by TTM, possibly because of endogenous formation of TTM from the reaction of AM with sulphide in rumen digesta. The in vitro addition of sulphide alone had no effect on the solubility of $\mathrm{Cu}$. Bird (1970) has shown that increases in the concentration of sulphide in rumen fluid from 0.54 to $3.0 \mathrm{mg} \mathrm{S} / 1$ caused by dietary supplements of sulphate or cysteine, decreased the concentration of $\mathrm{Cu}$ in the fluid phase of rumen contents. However, further increases in the sulphide concentration to $6.0 \mathrm{mg} \mathrm{S} / 1$ had no additional effect. In our experiments the sulphide concentration was between 5.8 and $6.3 \mathrm{mg} \mathrm{S} / 1$, so the lack of effect of sulphide on $\mathrm{Cu}$ solubility is in accord with the results of Bird (1970).

The dramatic changes in the distribution and chemical forms of $\mathrm{Cu}$ caused by the presence of TTM or AM in rumen digesta are potentially significant for $\mathrm{Cu}$ absorption further along the digestive tract. For instance, if Mo compounds cause $\mathrm{Cu}$ to become tightly bound to lignin, or to poorly digested proteins, less $\mathrm{Cu}$ will be absorbed from the intestines. Also, partial digestion of Mo-containing proteins may result in the release of Mo-containing peptides and amino acids and if such compounds are absorbed and have an affinity for $\mathrm{Cu}$ they may interfere with $\mathrm{Cu}$ metabolism. In a previous paper (Allen \& Gawthorne, 1985) we have reported that one such compound (cysteine-Mo-sulphide) causes some of the systemic signs of Mo-induced $\mathrm{Cu}$ deficiency. Price \& Chesters (1985) supplemented the diet of sheep with AM and subsequently gave samples of rumen contents from those animals to $\mathrm{Cu}$-deficient rats. The addition of Mo to the diet substantially decreased the availability of $\mathrm{Cu}$ for restoration of the activity of cytochrome $c$ oxidase $(E C 1.9 .3 .1)$ in the intestines of the rats.

The decrease in TCA-solubility of $\mathrm{Cu}$ in rumen contents brought about by AM and TTM supplements is similar to that observed in plasma when animals consume diets containing high concentrations of Mo and S (Smith \& Wright, 1975; Bremner \& Young, 1978). In sheep, Smith \& Wright (1975) and Bremner \& Young (1978) found that $\mathrm{Cu}$ was bound to Mo-containing plasma proteins, including albumin. Various attempts have been made to explain the mechanism of formation of TCA-insoluble $\mathrm{Cu}$, including co-precipitation of $\mathrm{Cu}$ thiomolybdates, or $\mathrm{Cu}$ sulphide and $\mathrm{Mo}$ disulphide with denatured proteins (Dick et al. 1975; Mason, 1982) or the formation of acid-insoluble $\mathrm{Cu}-\mathrm{Mo}$ complexes with protein (Smith \& Wright, 1975; Mills \& Bremner, 1980). Recent evidence suggests that the mechanism is quite different. In in vivo studies with ${ }^{35} \mathrm{~S}$ and ${ }^{99} \mathrm{Mo}-$ labelled trithiomolybdate and TTM, Hynes et al. (1984) found that thiomolybdates were bound to plasma albumin and that the binding was reversible and unaffected by the TCA-insoluble $\mathrm{Cu}$ also associated with the albumin. It appeared that $\mathrm{Cu}$ and thiomolybdates were not at the same site, and 
did not react with each other, but that thiomolybdates modified the way in which $\mathrm{Cu}$ was bound by albumin. The possibility that thiomolybdates protect a pool of reactive sulphide on the molecule, enabling it to react with $\mathrm{Cu}$ to form $\mathrm{CuS}$ before or during acidification was also claimed to be unlikely in the light of this evidence. The presence of high-MW compounds with tightly-bound $\mathrm{Cu}$ in detergent extracts of TCA precipitates (Fig. 1), in rumen contents suggests that $\mathrm{Cu}$ becomes tightly bound to dietary and microbial proteins in the presence of TTM, possibly by a mechanism similar to that described for albumin by Hynes et al. (1984).

Clarke \& Laurie (1980) showed that in pure aqueous solutions TTM formation only occurred at sulphide:Mo values of 10:1. However, Bray et al. (1982), using a Rusitec artificial rumen apparatus, observed a $32 \%$ conversion to TTM at sulphide: Mo values of 3.6: 1 . It has been proposed that local concentrations of sulphide in rumen contents may be sufficient to generate TTM (El Gallad et al. 1983) and it is known that an equilibrium is established between $\mathrm{AM}, \mathrm{H}_{2} \mathrm{~S}$, and the mono-, di-, tri- and tetrathiomolybdate species in aqueous solutions (Weber et al. 1979; Harmer \& Sykes, 1980). Although only a low concentration of TTM is formed at equilibrium in pure aqueous solutions, we suggest that the continual removal of TTM via binding with proteins and other macromolecules in rumen contents could alter the position of equilibrium and result in the formation of more TTM than would be expected from solution chemistry.

Suttle \& Field (1983) repleted hypocupraemic ewes with a dietary $\mathrm{Cu}$ supplement in the presence of molybdate, dithiomolybdate or TTM together with a low or a high concentration of dietary S. They found that the effect of the S supplement was dominant, causing molybdate and dithiomolybdate to alter $\mathrm{Cu}$ absorption in the same way as TTM. It was concluded that TTM can form poorly absorbed complexes that do not contain $\mathrm{Cu}$ and that systemic effects on $\mathrm{Cu}$ metabolism will only occur in ruminants when there is an excess of absorbable forms after combination with $\mathrm{Cu}$ has occurred. The results of our experiments suggest that the 'poorly-absorbed complexes' referred to by Suttle \& Field (1983) are complexes between TTM and comporents such as proteins in the solid phase of rumen digesta.

Although TTM mimics the effects of molybdate plus sulphate in rumen contents it is evidently not the species of thiomolybdate that is absorbed. Mason et al. (1982a) have demonstrated that ${ }^{99} \mathrm{Mo}$-labelled trithiomolybdate or TTM is found in plasma following rumen infusion of the respective preformed compound. These authors also found that diand trithiomolybdate and not TTM appeared in plasma after infusion of molybdate in sheep fed on a high-S diet. They concluded that di- and trithiomolybdate may be of more importance than TTM in inducing pathological signs of $\mathrm{Cu}$ deficiency in sheep.

The absence of TTM systemically can be rationalized if account is taken of the interaction with rumen contents. The rapid association of TTM with the solids fraction of rumen digesta and the slow rate of formation of TTM from di- and trithiomolybdate (Aymonino et al. 1969) could together limit the action of TTM to the gastrointestinal tract and promote the absorption of the other species at high concentrations of Mo and $\mathrm{S}$ in the diet. TTM may be more strongly bound to the solids than the other species, or may lose a $S$ atom during the binding so that trithiomolybdate is the predominant species that is available for absorption. However, it is also possible that significant amounts of TTM are not produced in the rumen but that trithiomolybdate is the active species in ruminants, as implied by Mason (1982).

Our results do not enable a decision to be made between trithiomolybdate or TTM as the active intermediary in the $\mathrm{Cu}-\mathrm{Mo}-\mathrm{S}$ interaction. The effects of $\mathrm{AM}$ added in vivo or in vitro to rumen contents were as if TTM had been formed in situ. 
The authors are grateful to the Rural and Industries Bank of Western Australia for a fellowship for one of us (J.D.A.) and financial support for the project. They also thank $\mathrm{Mr}$ M. McKenzie, Mr K. Chong and Ms K. Burroughs for care of the animals and technical assistance.

\section{REFERENCES}

Allen, J. D. \& Gawthorne, J. M. (1985). In Trace Elements in Man and Animals (TEMA-5), pp. 361-363 [C. Mills, 1. Bremner and J. Chesters, editors], Slough: Commonwealth Agricultural Bureaux.

Aymonino, P. J., Ranade, A. C., Diemann, E. \& Muller, A. (1969). Zeitschrift für Anorgonische und Allgemeine Chemie 371, 300-305.

Bingley, J. B. (1963). Agricultural and Food Chemistry 11, 130-131.

Bird, P. R. (1970). Proceedings of the Australian Society of Animal Production 8, 212-218.

Bray, A. C., Suttle, N. F. \& Field, A. C. (1982). Proceedings of the Nutrition Society 41, 67A.

Bremner, I. (1970). British Journal of Nutrition 24, 769-783.

Bremner, I., Mills, C. F. \& Young, B. W. (1982). Journal of Inorganic Biochemistry 16, 109-119.

Bremner, I. \& Young, B. W. (1978). British Journal of Nutrition 39, 325-336.

Chesters, J. K., Will, A. M., Price, J. \& Mills, C. F. (1982). Proceedings of the Nutrition Society 41, 139 A.

Clarke, N. J. \& Laurie, S. H. (1980). Journal of Inorganic Biochemistry 12, 37-43.

Dick, A. T. (1956). In Organic Nitrogen Metabolism, pp. 445-473 [W. McElroy and B. Glass, editors]. Baltimore: Johns Hopkins Press.

Dick, A. T., Dewey, D. W. \& Gawthorne, J. M. (1975). Journal of Agricultural Science, Cambridge 85, $567-568$.

Durand, M. \& Kawashima, R. (1979). In Digestive Physiology and Metabolism in Ruminants, pp. 375-408 [Y. Ruckebusch and P. Thivend, editors]. Lancaster: MTP Press Ltd.

El Gallad, T. T., Mills, C. F., Bremner, I. \& Summers, R. (1983). Journal of Inorganic Biochemistry 18, 323-334.

Gawthorne, J. M., Allen, J. D. \& Nader, C. J. (1985). In Trace Elements in Man and Animals (TEMA-5), pp. 346-351 [C. Mills, I. Bremner and J. Chesters, editors]. Slough: Commonwealth Agricultural Bureaux.

Gawthorne, J. M. \& Nader, C. J. (1976). British Journal of Nutrition 35, 11-23.

Grace, N. D. \& Suttle, N. F. (1979) British Journal of Nutrition 41, $125-136$.

Harmer, M. A. \& Sykes, A. G. (1980). Inorganic Chemistry 19, 2881-2885.

Hewitt, E. J. (1983). In Metals and Micronutrients: Uptake and Utilization by Plants, pp. 277-290 [D. Robb and W. Pierpoint, editors]. New York: Academic Press.

Hynes, M., Lamand, M., Montel, G. \& Mason, J. (1984). British Journal of Nutrition 52, 149-158.

Mason, J. (1982). Irish Veterinary Journal 36, 164-168.

Mason, J., Kelleher, C. A. \& Letters, J. (1982a). British Journal of Nutrition 48, 391-397.

Mason, J., Lamand, M. \& Kelleher, C. A. (1982b). Journal of Comparative Pathology 92, 509-518.

Mills, C. F. \& Bremner, I. (1980). In Molybdenum and Molybdenum-Containing Enzymes, pp. $519-542$ [M. P. Coughlan editor]. Oxford: Pergamon Press.

Mills, C. F., El Gallad, T. T., Bremner, I. \& Wenham, G. (1981). Journal of Inorganic Biochemistry 14, 163-175.

Price, J. \& Chesters, J. K. (1985). British Journal of Nutrition 53, 323-336.

Smith, B. S. W. \& Wright, H. (1975). Clinica Chemica Acta 62, 55-63.

Smith, R. M. \& Marston, H. R. (1970). British Journal of Nutrition 24, 857-877.

Suttle, N. F. \& Field, A. C. (1983). Journal of Comparative Pathology 93, 379-389.

Van Soest, P. J. (1966). Journal of the American Organization of Agricultural Chemists 49, 546-551.

Van Soest, P. J. \& Wine, R. H. (1967). Journal of the American Organization of Agricultural Chemists 50, $50-55$.

Weber, K. M., Leaver, D. D. \& Wedd, A. G. (1979). British Journal of Nutrition 41, 403-405.

Zumft, W. G. (1978). European Journal of Biochemistry 91, 345-350. 